\title{
THE NATURAL AND MIGRATORY MOVEMENT OF THE RURAL POPULATION OF THE BANAT MOUNTAINS (1993-2016)
}

\author{
Mădălin-Sebastian LUNG * \\ Babeș-Bolyai University, Doctoral School of Geography, Faculty of Geography, 5-7 Clinicilor Street, Cluj-Napoca, \\ România, e-mail: lungmadalin@yahoo.com \\ Sorin-Constantin BAN \\ Liceul Tehnologic „Vlădeasa” Huedin, 78-80 Horea Street, Huedin, România, e-mail: ban_sorin@ @ahoo.com
}

Citation: Lung, M.-S., \& Ban, S.-C. (2021). The Natural and Migratory Movement of the Rural Population of the Banat Mountains (1993-2016). Revista Română de Geografie Politică, 23(2), 80-91. https://doi.org/10.30892/rrgp.232102-351

\begin{abstract}
The article is based on the study of population dynamics in the rural area of the Banat Mountains. The study period ranged from 1993 to 2016. The aim of the paper was to observe the numerical evolution of the population and to make calculations on the evolution of some demographic indicators. Demographic indicators such as the natality, mortality, natural growth, natural, migratory movement and migratory growth of communes have been analyzed over the period mentioned. A first objective was to physically and then administratively delineate the Banat Mountains. The second objective was to obtain the necessary numerical data, then to process the data for each indicator. Data processing resulted in a series of indicator rates, and in addition, graphs were developed with the numerical evolution of newborns and deaths. The numerical data on the number of newborns and deaths were taken from the website of the National Institute of Statistics. There have been introduced in the Microsoft Excel 2013 program a few graphs. Also, through Microsoft Excel 2013, rates for demographic indicators were calculated, and then the results obtained were introduced into Arc Gis version 10.3. Finally, a series of maps on the territorial distribution of values for each indicator was generated.
\end{abstract}

Key words: natural dynamics, migratory dynamics, rural population, Banat Mountains 


\section{INTRODUCTION}

The Banat Mountains are a mountain group belonging to the Western Carpathians. In the south, they are bounded by the Danube River, in the eastern part of the Timis-Cerna aisle, north of the Lugoj Plain, and in the west are bounded by a series of hills. The Banat Mountains have shown interest in research due to the abundant historical past. Studies have been carried out aiming at the research of relief dynamics and studies on the population, tourism activities.

The Banat Mountains came to the attention of the researchers (Grigore, 1965; Olaru, 1995; Olaru, 1996; Olaru, 2000; Lazăr, 2011; Ianăș, 2011) who have conducted various studies on the dynamics of relief, population and tourist activities. Other studies have been conducted on other areas of the country on population dynamics (Mălăescu and Mihăescu, 2008; Mihalca, 2010; Niță, 2010; Vîlcea, 2011; Pavel and Fonogea, 2011; Fonogea et al., 2012; Tofan, 2012; Persu, 2017, Lung, 2018; Lung and Gligor, 2018; Lung and Diaconescu, 2019; Lung and Mureșan, 2020). Population has shown interest in research for researchers around the world (Muhsam, 1987; Dellapergola, 2001; Josipovic and Repolusk, 2003; Leridon, 2004; Attané and Barbieri, 2009; Prioux and Mazuy, 2009; Kerbler, 2015; De Luca Barrusse, 2018; Franke and Kulu, 2018; Kozina, 2018) with demographic studies from different perspectives.

The Banat Mountains are rich in subsoil resources, which led to their anthroposis during historical periods. Due to industrialization during the socialist period, the population thrived because there were jobs and the economy was based on industrial activities. After 1989, massive restructurings took place in the industrial sector, which triggered economic regression and subsequently demographic regression. The purpose of the study is to carry out radiography on demography in the Banat Mountains' rural area after the socialist period. In this way, demographic indicators such as natality, mortality and natural growth were taken into account. Also, the demographic evolution after 1989 was taken into account.

\section{METHODOLOGY}

The geomorphological map was used for the physical delimitation of the studied area (Posea and Badea, 1984). The administrative delimitation was made by overlapping administrative-territorial units above the contouring physical boundary. All the administrative-territorial units whose estates, overlapping even partially, over the mountain unit were included in the western mountainous area (Surd et al., 2017). After the application of the method, 38 administrative-territorial units were formed, which make up the rural area of the Banat Mountains. After the administrative delimitation was followed the identification of the rural space, the next step is to get the necessary numerical data. Obtaining data for the targeted demographic indicators was made through the Tempo-Online Platform accessible on the National Institute of Statistics website. After the acquisition of the numerical data, the rates of the three indicators were calculated. Calculation of rates was made using Microsoft Excel 2013, and will be processed with Arc Gis version 10.3. After their processing, a series of maps were obtained, and in addition they were created graphs to highlight as clearly as possible the evolution of the investigated indicators in the period 1993-2016. 


\section{RESULTS AND DISCUSSIONS}

\section{Numerical evolution of the population}

After the socialist period, the population of the Banat Mountains' rural area began to decline significantly. In 1993, the rural area registered 80,467 people, and in 2000 the population would decrease to 74,557 people. The demographic decline in the eight years was $7.3 \%$, which means almost half of the entire 1993-2016 period when the population dropped by $16.8 \%$. From 2010 to 2016 , in the six years, the population declined by $4.7 \%$. The rural area of the Banat Mountains has a small population, so in 2016 the 38 communes had a population of 66,911 , and the largest city, Resita, had 87,951 inhabitants. The share of rural population in the Banat Mountains in 2016 was $46.7 \%$ (figure 1).

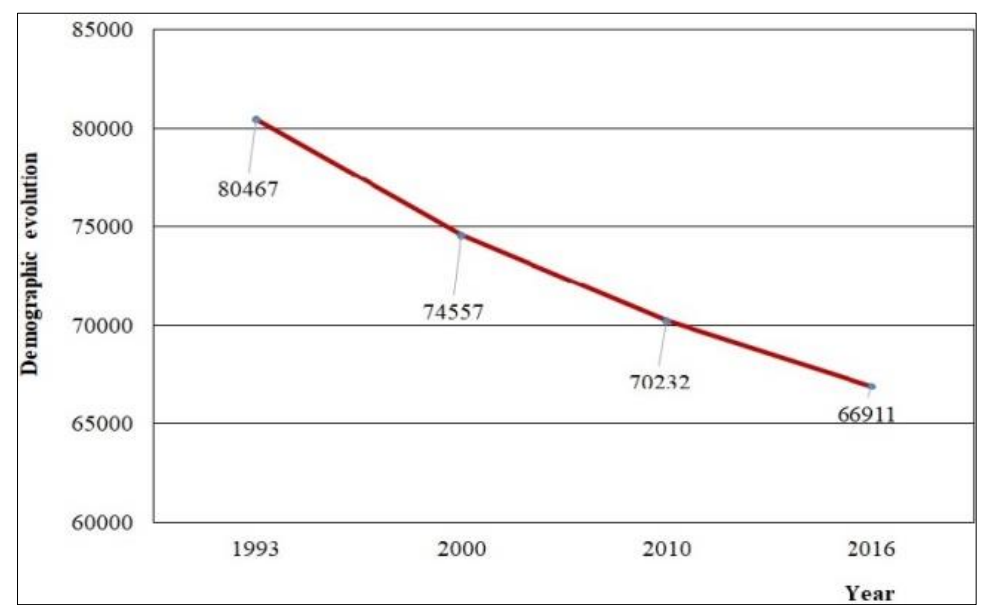

Figure 1. Demographic evolution in the rural area of the Banat Mountains in the period 1993-2016

(Source: data processed after the NIS)

\section{The evolution of birth}

Natality in the rural area between 1993 and 2016 had values between $1 \%$ and $20 \%$.

The lowest values between 3-5\%o were in four communes respectively Brebu Nou (3.6 \%o), Cărbunari (4.5\%o), Mehadica (4.9\%o) and Sasca Montană (5.0\%o). Of the 38 communes, 34 were placed with birth rates between 1-10\%o. Eșelnița commune had $10 \%$, followed closely by the Văliug and Coronini, which had rates of $9.9 \%$, respectively Socol commune with $9.1 \%$. The maximum birth rates in the rural area of the Banat Mountains in the period 1993-2016 were in only four communes. The highest value in the whole rural area was in Dognecea 14.2 \%o, Ocna de Fier 12.0 \%o, Gârnic $11.8 \%$ ond Şopotu Nou $10.2 \%$ o (figure 2)

In terms of percentage, the territorial distribution of birth rates is dominated by values between $1-10 \%$, in $89 \%$ proportion. 


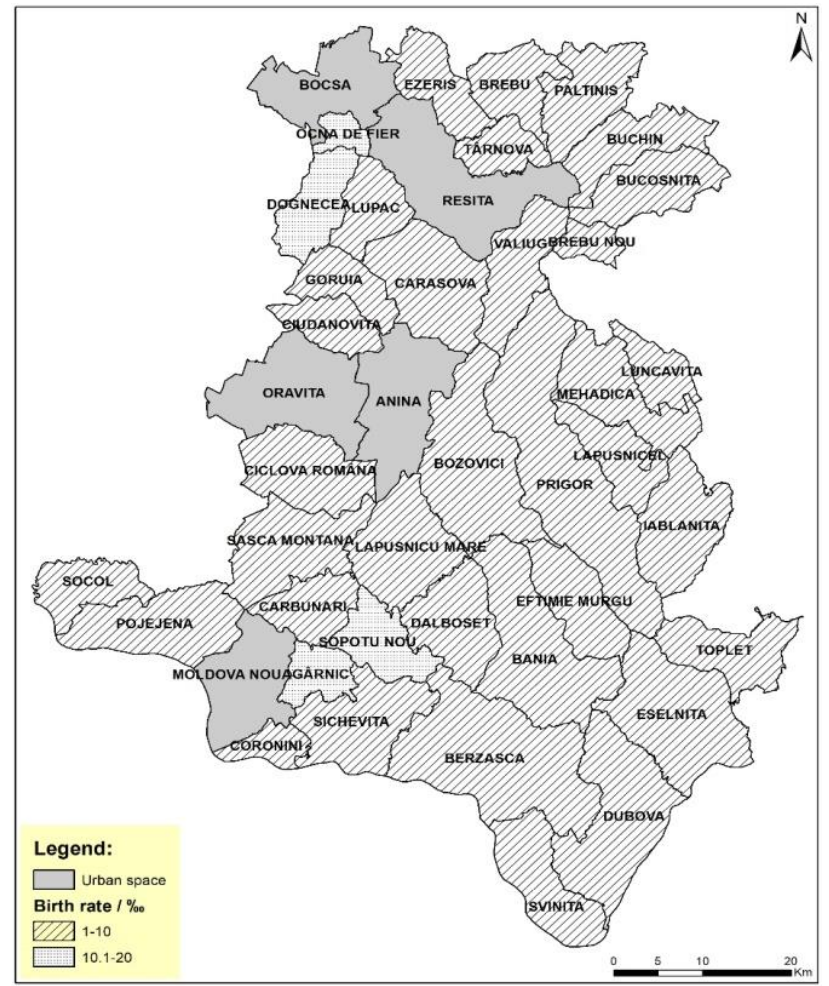

Figure 2. Distribution of birth rates in the period 1993-2016 (Source: data processed after the NIS)

\section{Numerical evolution of newborns}

Your birth number has been steadily decreasing by 2010, and in 2016 the number will grow very little with only three newborns. Throughout the time span, the number of newborns was 2,398 children.

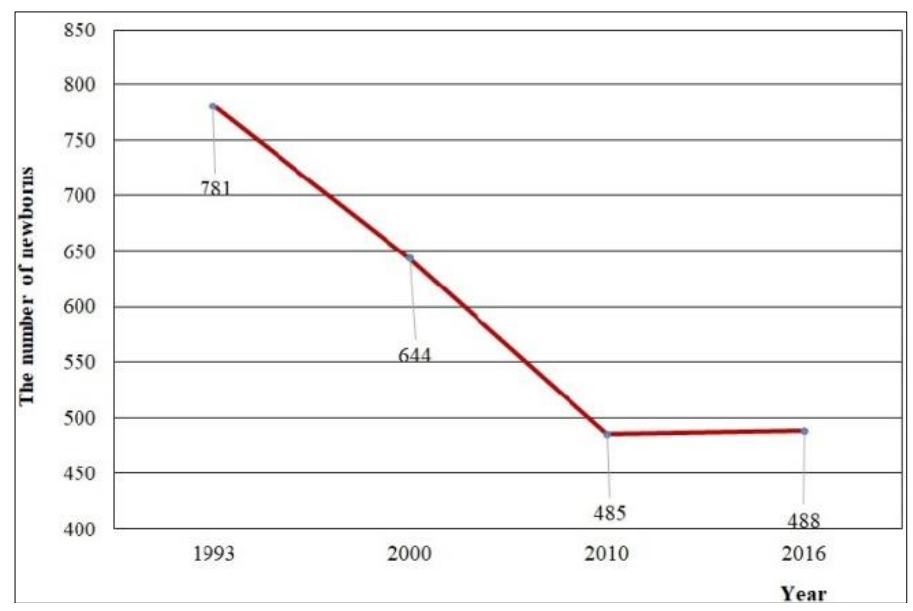

Figure 3. Numerical evolution of newborns

(Source: data processed after the NIS) 
The maximum was recorded in 1993 when 781 children were born, and in the next eight years, in 2000, the number dropped to 644. The decrease was $17.6 \%$. Over the next ten years, the number of babies dropped from 644 to 485 , which means a decrease of 159 children. Percentage decrease was $24.7 \%$ in the ten years 2000-2010. From 1993 to 2016, the decrease in the number of newborns in the rural area of the Banat Mountains was $37.6 \%$. Only six of the 38 have registered over the period 1993-2016 a number of newborn babies over 100. The six are: Dognecea with 123, Eşelnița with 116, Berzasca with 113, Carassova with 105, Prigor and Bucosnita with 101. The lowest value was in Brebu Nou commune of only four newborns, given that the entire commune had in 2002 only 87 inhabitants according to the data from the census (figure 3)

\section{Evolution of mortality}

The mortality rates in the Banat Mountains rural area are among the highest values, which are distributed throughout rural areas. Of the 38 communes, only two have lower mortality rates with values between 1-10\%. The communes are: Brebu Nou with $1.0 \%$ and Coronini with $8.7 \%$ o. The two are the only ones who have had mortality rates below $10 \%$ throughout the entire period. The maxims were recorded in eight communes: Cărbunari $(20.6$ \%o), Ezeriş (20.8 \%o), Târnova (20.9 \%o), Goruia (22.6 \%o), Ciclova Română (23.3 $\%$ ), Brebu (24.1\%o) ) and Sasca Montană (27.2\%o). The majority of administrative-territorial units (28 out of 38 ) are in the range of 10.1-20\%o (figure 4).

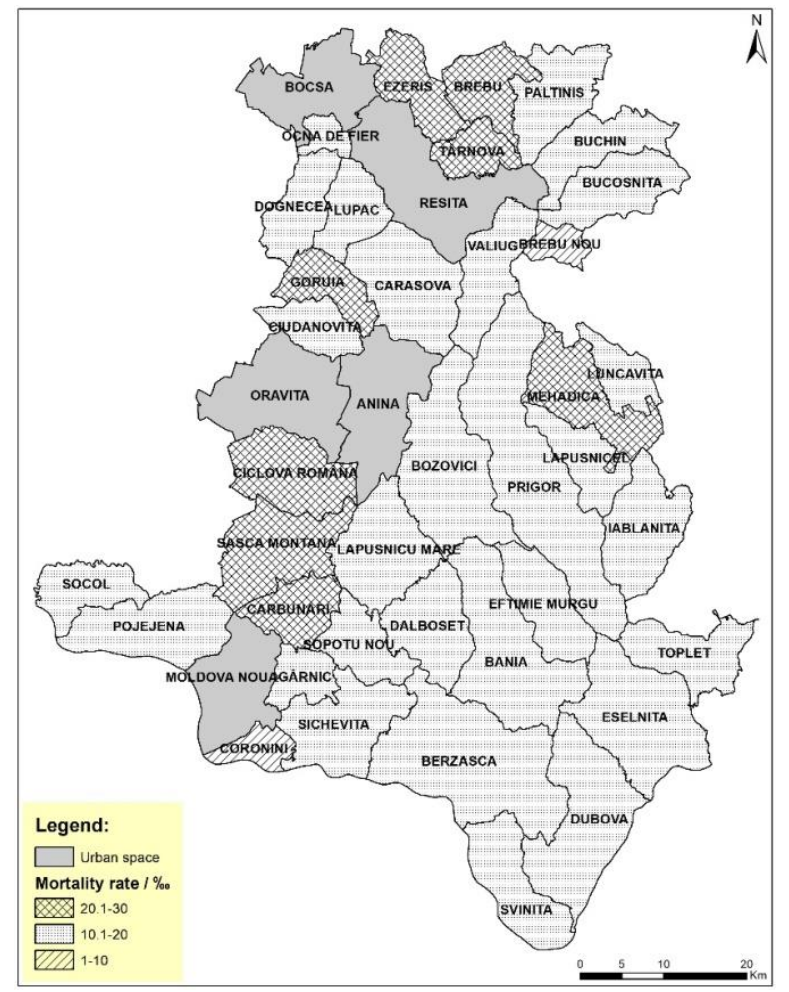

Figure 4. Distribution of mortality rates in the period 1993-2016 (Source: data processed after the NIS) 
Unfortunately, the distribution of mortality rates shows that the rural population in the Banat Mountains faces major demographic failures. Only, the communes of the Coronini and the Brebu Nou have slightly lower rates, the rest having high values, increasing continuously. Among the highest mortality rates are common where in the socialist period prospered the mining industry. After 1989, when the socialist regime was over, the mining industry was destructured, following the emergence of far-reaching negative socio-economic phenomena. They put their mark on the living standards of the population, which without the object of work could hardly prosper. They followed migrations of the young demgraphic component, behind remaining elders. Many miners in the mining communes suffered from diseases characteristic of the mining environment, leading to their exit from the system before the weather. Class of rates ranging from 10.1-20\%o dominates clearly with $74 \%$ of the territory, the second being class 20.1-30 with $21 \%$, respectively with grades $1-10 \%$ with only $5 \%$.

\section{Numerical evolution of deaths}

The number of deaths in the rural area of the Banat Mountains between 1993 and 2016 was 4,923. From 1993 to 2016 the numerical evolution of deaths was downward but with values above the number of births. The year 1993 recorded the maximum of 1443 deaths, and in 2000 the number would reach 1,273 with $170(11.8 \%)$ less than in 1993. During the first decade of the $21 \mathrm{st}$, 2000-2010, the decrease in deaths continued by $5.9 \%$, with the largest decrease in the studied period between 2010-2016, a decrease of $16 \%$. The highest values were in 15 communes each with more than 150 deaths. Three communes registered over 200 deaths, Pojejena 219, Berzasca 227 and Bozovici 251. Reporting the number of deaths in the period 1993-2016 to the population registered in 2016, the Pojejena population decreased by $7.7 \%$, the municipality of Berzasca by $8.3 \%$ and the municipality of Bozovici by $8.4 \%$. From 1993 to 2016, deaths declined by $30.1 \%$ (figure 5).

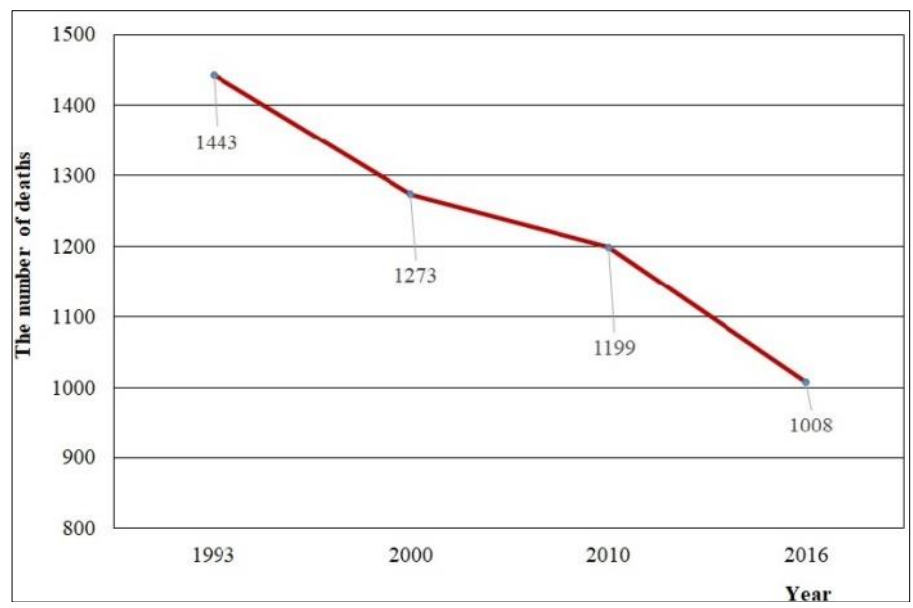

Figure 5. The numerical evolution of deaths (Source: data processed after the NIS) 


\section{Evolution of natural growth}

The continuing decline in deaths has not helped to record positive natural enhancement values in only three of the Dognecea, Brebu Nou and Coronini communities. The causes of the natural spores of these three communes have different origins. Dognecea was a well-industrialised commune, but after the disappearance of industry, the population began to enter other fields of activity, even to work in neighbouring administrative units. Many of the houses were bought by people from Timiş County, who wanted a quiet place with fresh air after the closure of the industry. Brebu Nou, is a commune in which there is no ethnic majority, the ethnic structure being divided between Romanians, Germans and Hungarians. Basically, the birth policies of each ethnicity have resulted in positive natural growth. The commune of Coronini continues to thrive due to its geographic position at the banks of the Danube. The population is trained in tourist and fishing activities. Most of the Banat Mountains' rural area is subject to negative values of natural growth. The Sasca Montană commune had the lowest natural increase $(-22.3 \%$ o) followed by another 13 administrative units (Lăpuşnicel $-10.2 \%$ o, Pojejena $-10.4 \%$ o, Sichevița $-11.0 \%$, Dalboşeț - 11.3 \%o, Bozovici - 12.6 \%o, Buchin - $13.1 \%$ o, Târnova -13.7 \%o, Ezeriș -14.1 \%o, Ciclova Română -14.8 \%o, Goruia -15.0 \%o, Cărbunari -16.0 \%o, Brebu $-17.4 \%$, Mehadica -20.0 \%o). 21 municipalities had natural increase values between 0 and $-10 \%$ (figure 6).

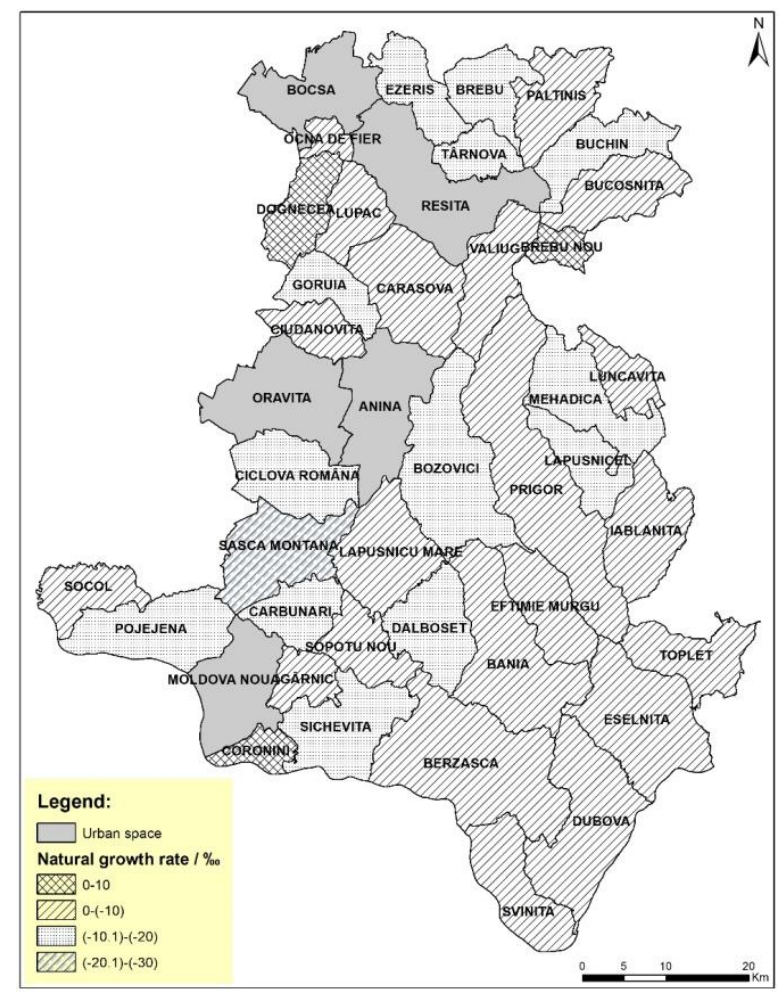

Figure 6. Distribution of natural growth rates during 1993-2016 (Source: data processed after the NIS) 


\section{Dynamics of emigrations}

Between 1993 and 2016, 4,524 people left the countryside of the Banat Mountains. Out of the 38 communes only three (Bucossnița $9.7 \%$, Lupac 8.7 $\%$, Carașova $6.8 \%$ o) the emigration rate (figure 9) was below $10 \%$. In the opposite direction, the communes with the highest departure rates were Brebu Nou with $42.9 \%$ and Ciudanovița with $42.1 \%$. Brebu Nou is an administrative unit in which there is no ethnic majority, and the number of Germans has been continuously decreasing. Former settlers, some of them have returned to their places of origin. In 1993, the population of Brebu Nou commune was 247 inhabitants, with the population census falling to 119 inhabitants at the 2011 census. The demographic decrease of the commune in the 20 years was $48.2 \%$. For much of the population $(27 \%)$, the ethnic situation is unknown. Ciudanovița is a commune in which the departures have been accentuated due to anthroposis. As early as the socialist period, uranium deposits were found and exploited in the administrative territory. Unfortunately, these have been exploited without taking certain measures to protect the population. The high level of radioactivity has in time led to the illness of the commune's workers and inhabitants.

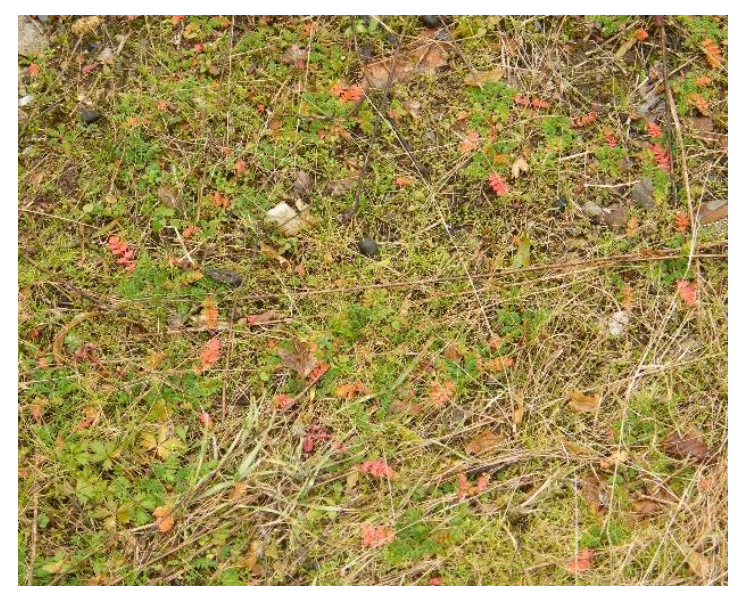

Figure 7. Normal plant cover

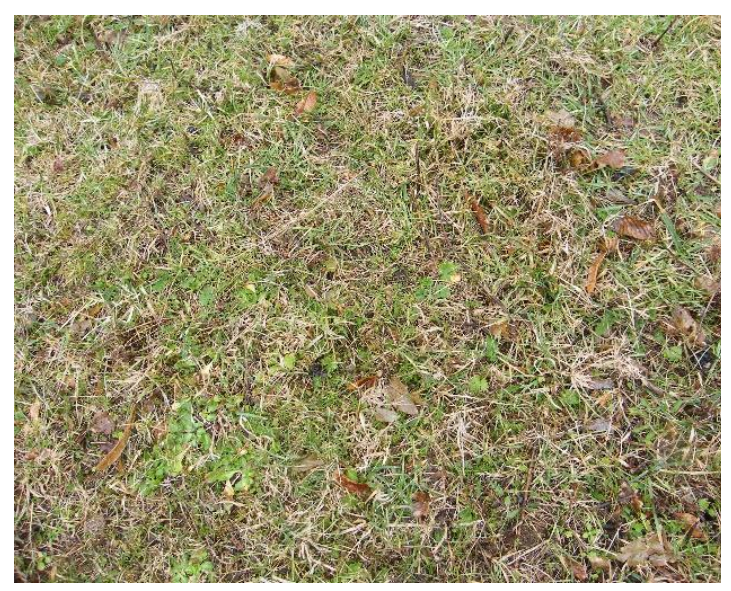

Figure 8. Plant cover on the dump

Massive departures began after 1989, when the exploitation activities ceased and the exploitation areas remained uncologized. Authorities have not been involved in greening activities, many of the heaps being only briefly fenced. Even after decades, radioactivity can be seen in the evolution of the plant cover. The chromaticity is quite different between the vegetation developed on the dump and around the heap (figure 7 ) and the vegetation at a greater distance from the dump (figure 8).

The weights of migration rates in the Banat Mountains rural area represent a majority (71\%) of the values between 10.1-20\%. The second place is occupied by the values between 20.1-30\%o with a weight of $16 \%$. Looking at these weights, we can say that the rural area is experiencing the depopulation phenomenon, the values of departures being among the highest (figure 10). 


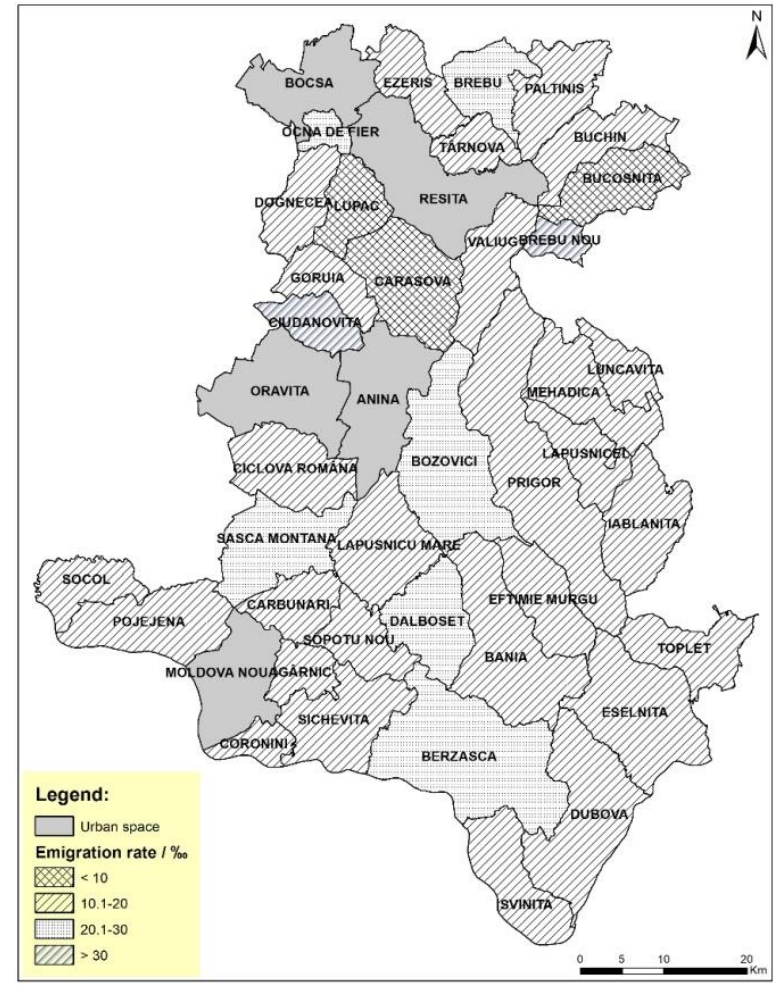

Figure 9. Distribution of emigration rates (Source: data processed after the NIS)

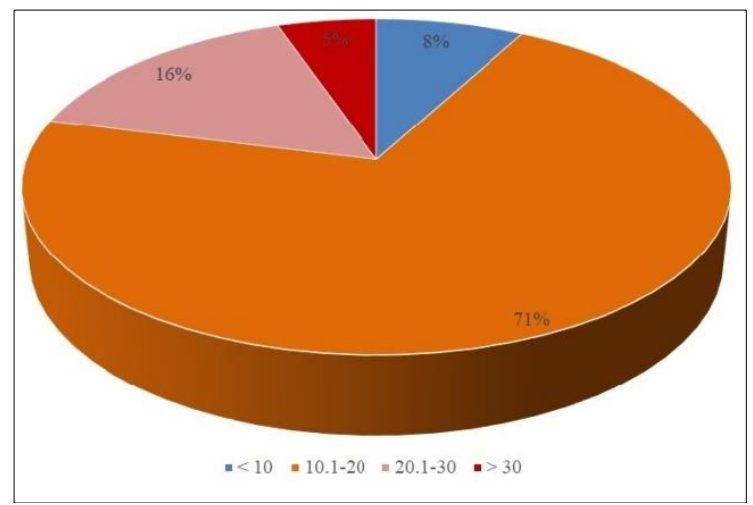

Figure 10. The weights of emigration rates (Source: data processed after the NIS)

\section{Immigration dynamics}

For the entire timeframe analyzed the number of establishments was 4,257. Regarding the immigration of the population, eight communes were recorded (Coronini 9.9 \%o, Gârnic 9.9 \%o, Eftimie Murgu 8.8 \%o, Lupac 8.8 \%o, Prigor $8.8 \%$, Şopotu Nou $7.9 \%$, Luncavița $7.8 \%$, Caraşova $5.9 \%$ ) was below 10 \%o. Another eight communes (Ezeriş 26.3 \%o, Brebu 25.1 \%o, Buchin 23.8 \%o, Sasca Montana 23.5 \%o, Văliug 23.4 \%o, Ciclova Română 23.0 \%o, Goruia 
$23.0 \%$, Bozovici $22.0 \%$ ) recorded the highest values of immigration. 22 communes had immigration rates ranging from 10.1 to $20 \%$ (figure 12).

Immigration rates are ranked first with $58 \%$ values between 10.1-20\%o and the second place with equal weights are below $10 \%$ and between 20.1-30 \%o (figure 11).

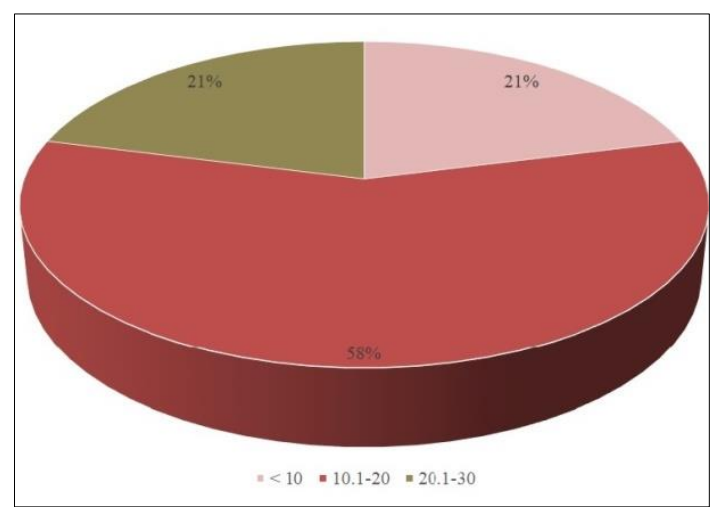

Figure 11. The weights of immigration rates (Source: data processed after the NIS)

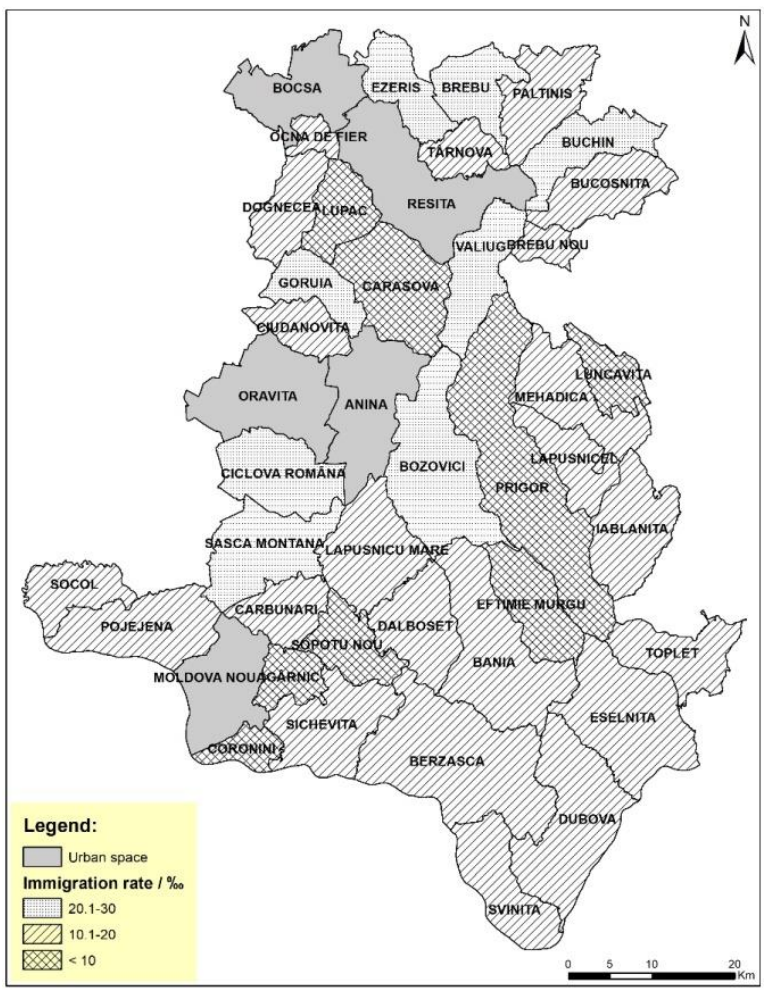

Figure 12. Distribution of immigration rates (Source: data processed after the NIS) 


\section{Migratory growth}

The migratory increase of the population in the rural area of the Banat Mountains is negative. Between 1993 and 2016, 4,257 people were settled in the countryside and 4,524 people left. It follows that the migration rate has a negative value.

\section{CONCLUSIONS}

The rural area of the Banat Mountains is subject to risky demographic phenomena. The period 1993-2016 was a poor demographic with values of negative natural growth for most communes. Of the 38 communes, only three recorded natural positive growth (Brebu Nou, Coronini, Dognecea). The highest negative value was in Sasca Montana commune to $-20.1 \%$. For the whole period the number of deaths was well above the number of newborns, respectively mortality values were above birth rates. The numerical evolution of the population in the rural area of the Banat Mountains has been steadily decreasing over the whole period studied.

The migratory dynamics was negative, so the departure values were higher than the set values. The territorial distribution of emigration and immigration rates is a homogeneous one in which the highest and lowest values can be observed.

Consequently, the rural area of the Banat Mountains is experiencing real demographic dysfunctions. Negative values of natural growth, coupled with negative values of migratory growth, are converging towards deploying and deploying demographic risk phenomena such as depopulation.

\section{REFERENCES}

Attané, I., \& Barbieri, M. (2009). The Demography of East and Southeast Asia from the 1950s to the 2000s. Population, 64(1), 9-146.

De Luca Barrusse, V. (2018). The "Denatality Complex": The Demographic Argument in the Birth Control Debate in France, 1956-1967. Population, 73(1), 9-33.

Dellapergola, S. (2001). Jerusalem's Population, 1995-2020: Demography, Multiculturalism and Urban Policies. European Journal of Population, 17(2), 165-199.

Fonogea, S., Gligor, V., \& Puiu, V. (2012). Dinamica populației din bazinul hidrografic al Bistriței Ardelene în intervalul 1850-2010 [Population dynamics in the river basin of Bistriței Ardelene in the range 1850-2010]. Geographia Napocensis, VI(1), 89-100.

Franke, S., \& Kulu, H. (2018). Mortality Differences by Partnership Status in England and Wales: The Effect of Living Arrangements or Health Selection?. European Journal of Population, 34(1), 87-118.

Grigore, M. (1965). Relieful crio-nival din Munții Banatului [The Crio-nival relief in the Banat mountains]. Edit. Academiei Republicii Socialiste România, București.

Ianăş, Ana-Neli (2011). Țara Almăjului: studiu de geografie regională [Land of Almăjului: regional Geography Study]. Edit. Presa Universitară Clujeană, Cluj-Napoca.

Jani, K. (2018). Demographic characteristics of creative workers: under-activated development potentials in Slovenia?. Acta Geographica Slovenica, 58(2), 111-121.

Josipovic, D., \& Repolusk, P. (2003). Demographic Characteristics of the Romany in Prekmurje. Acta Geographica Slovenica, 43(1), 127-147.

Kerbler, B. (2015). Population aging in Slovenia: A spatial perspective. Acta Geographica Slovenica, 55(2), 303-317.

Lazăr, A. (2011). Religie şi dezvoltare în Munții Banatului : studiu de geografia religiilor [Religion and development in the Banat Mountains: Study of the Geography of religions]. Edit. Risoprint, Cluj-Napoca.

Leridon, H. (2004). The Demography of a Learned Society. Population, 59(1): 81-114. 
Lung, M-S. (2018). The natural dynamics of the rural population in Apuseni Mountains (2011 Census). Revista Română de Geografie Politică, 20(2), 41-48.

Lung, M-S., \& Diaconescu, L. (2019). Altitudinal Distribution of Population and Settlements in the Carpathian Mountain Space. Case Study : Romanian Carpathians. Revista Română de Geografie Politică, 21(1), 1-17, https://doi.org/10.30892/rrgp.211101-324

Lung, M-S., \& Gligor, V. (2018). Demographic changes in the urban space of Apuseni Mountains. Analele Universitătii din Oradea, Seria Geografie, 28(2) 164-173.

Lung, M-S., \& Mureșan, G-A. (2020). Natural dynamics of the demographic component in the Apuseni Mountains at the and ot the 20th century and beginning of the 21st century (19812018). Geographia Napocensis, 14(2), 7-13.

Mălăescu, S., \& Mihăescu, S. (2008). The dynamic of the demographic component of the Olt and Jiu bordered sub-carpathians in the transition period - as a premise of the economical and social development. Geographia Napocensis, 2 (1), 54-62.

Mihalca, A-I. (2010). Dinamica populației Microregiunii Târgu Lăpuș în perioada 1990-2009 [Dynamics of the population of the Târgu Lăpuş Microregion in the period 1990-2009]. Geographia Napocensis, 4(1), 89-100.

Muhsam, H.V. (1987). Mortality, population fluctuations and the nuclear danger, European Journal of Population. 2(3-4), 219-223.

National Institute of Statistics, Retrieved June 25, 2018 and October 28, 2021 from http:/ /www.ins

Niță, A. (2010). Aspects regarding the origin and evolution of the population and settlements in the Întorsura Buzăului Depression. Studia Geographia, 2, 93-104.

Olaru, M. (1995). Organizarea spațiului turistic în Munții Banatului [Organizing tourist space in Banat Mountains]. Banatica, 13, 263-276.

Olaru, M. (1996). Munții Banatului : resursele turistice naturale şi antropice [Banat Mountains: natural and anthropogenic tourist resources]. Edit. Hestia, Timișoara.

Olaru, M. (2000). Munții Banatului : amenajarea și dezvoltarea turistică [Banat Mountains: tourist Planning and development]. Edit. Hestia, Timișoara.

Pavel, I-H., \& Fonogea, S. (2011). Dinamica populației Țării Amlașului în perioada 2002-2009 [Population dynamics of the Land of Amlaşului in the period 2002-2009]. Geographia Napocensis, 5(1), 101-110.

Persu, M-R. (2017). Demographic changes in the rural area of the Southern Carpathians (19922011). Rev. Roum. Géogr./Rom. Journ. Geogr., 61(2): 139-149.

Prioux, F., \& Mazuy, M. (2009). Recent Demographic Developments in France: Tenth Anniversary of the PACS Civil Partnership, and Over a Million Contracting Parties. Population, 64(3), 393442.

Surd, V. et al. (2017). Așezările din Munții Apuseni [Settlements in the Apuseni Mountains]. Edit. Presa Universitară Clujeană, Cluj-Napoca.

Tofan, G-B. (2012). Drăgoiasa-Tulgheș depressionary alingment. The numerical evolution of population between 1850 and 2010. Studia Geographia, 1, 107-118.

Vîlcea, I-C. (2011). The characteristics of the evolution regarding the population growth in The Land Of Severin. Geographia Napocensis, 5(1), 49-58.

Submitted:

Octomber 15, 2021
Revised:

November 26, 2021
Accepted and published online:

December 22, 2021 